\title{
Circulating cell-free methylated DNA and lactate dehydrogenase release in colorectal cancer
}

\author{
Alexander B Philipp ${ }^{1}$, Dorothea Nagel ${ }^{2}$, Petra Stieber ${ }^{2}$, Rolf Lamerz', Isabel Thalhammer ${ }^{1}$, Andreas Herbst ${ }^{1}$ \\ and Frank T Kolligs ${ }^{1 *}$
}

\begin{abstract}
Background: Hypermethylation of DNA is an epigenetic alteration commonly found in colorectal cancer (CRC) and can also be detected in blood samples of cancer patients. Methylation of the genes helicase-like transcription factor (HLTF) and hyperplastic polyposis 1 (HPP1) have been proposed as prognostic, and neurogenin 1 (NEUROG1) as diagnostic biomarker. However the underlying mechanisms leading to the release of these genes are unclear. This study aimed at examining the possible correlation of the presence of methylated genes NEUROG1, HLTF and HPP1 in serum with tissue breakdown as a possible mechanism using serum lactate dehydrogenase (LDH) as a surrogate marker. Additionally the prognostic impact of these markers was examined.
\end{abstract}

Methods: Pretherapeutic serum samples from 259 patients from all cancer stages were analyzed. Presence of hypermethylation of the genes HLTF, HPP1, and NEUROG1 was examined using methylation-specific quantitative PCR (MethyLight). LDH was determined using an UV kinetic test.

Results: Hypermethylation of HLTF and HPP1 was detected significantly more often in patients with elevated LDH levels ( $32 \%$ vs. $12 \%[p=0.0005]$, and $68 \%$ vs. $11 \%[p<0.0001]$, respectively). Also, higher LDH values correlated with a higher percentage of a fully methylated reference in a linear fashion (Spearman correlation coefficient 0.18 for HLTF $[p=0.004] ; 0.49$ [p < .0001] for HPP1). No correlation between methylation of NEUROG1 and LDH was found in this study. Concerning the clinical characteristics, high levels of LDH as well as methylation of HLTF and HPP1 were significantly associated with larger and more advanced stages of CRC. Accordingly, these three markers were correlated with significantly shorter survival in the overall population. Moreover, all three identified patients with a worse prognosis in the subgroup of stage IV patients.

Conclusions: We were able to provide evidence that methylation of HLTF and especially HPP1 detected in serum is strongly correlated with cell death in CRC using LDH as surrogate marker. Additionally, we found that prognostic information is given by both HLTF and HPP1 as well as LDH. In sum, determining the methylation of HLTF and HPP1 in serum might be useful in order to identify patients with more aggressive tumors.

Keywords: Colorectal cancer, Dna methylation, HItf, Hpp1, Neurog1, Ldh

\section{Background}

Colorectal cancer (CRC) is the third most common cancer and the fourth most frequent cause of death from cancer worldwide with about 1.2 million cases and about 633,000 deaths in 2008 [1]. Despite significant advances in the last decades, especially patients with metastatic disease suffer from poor prognosis [2]. In addition to new therapeutic

\footnotetext{
*Correspondence: Frank.Kolligs@med.uni-muenchen.de

${ }^{1}$ Department of Medicine II, Ludwig-Maximilians-Universität München, Marchioninistr. 15, 81377 Munich, Germany

Full list of author information is available at the end of the article
}

options, biomarkers are needed that allow the identification of different subgroups of patients potentially benefitting from different treatment regimens and intensity.

In many human cancers aberrant hypermethylation of CpG islands is a common epigenetic DNA modification leading to transcriptional silencing of genes that is already detectable in early stages of carcinogenesis [3]. Genes found hypermethylated in colorectal cancer have many functions, including mismatch repair, cell-cycle regulation and cell differentiation [4]. Methylated tumor DNA cannot only be found in primary colorectal cancer 
tissue, but can also be detected in remote media like serum or stool and potentially be used as biomarkers for various purposes [5-7]. We have previously described methylation of the genes neurogenin 1 (NEUROG1) in serum and HIC1 in stool as diagnostic markers [8,9] and helicase-like transcription factor (HLTF) and hyperplastic polyposis 1 (HPP1), also known as transmembrane protein with EGF-like and two follistatin-like domains 2 (TMEFF2), as prognostic serum markers $[10,11]$.

NEUROG1 is a basic helix-loop-helix transcription factor which has been identified as one of the main players in neurosensory evolution and development, especially of the inner ear [12]. Moreover NEUROG1 has been described to be frequently hypermethylated in colorectal cancers and has been proposed as a marker to classify the CpGisland methylator phenotype in colorectal cancers [13,14].

HLTF is a transcription factor and a member of the SWI/SNF family of chromatin-remodeling factors [15]. The physiological function of HLTF has not yet been fully understood, but evidence for its association with genesis and progression of cancer exists [16]. Recently HLTF deficiency has been reported to significantly increase the formation of small intestinal adenocarcinoma and colon cancer in mice on a $A p c^{m i n /+}$ mutant background and to be associated with chromosomal instability [15]. Hypermethylation of HLTF can commonly be found in all stages of CRC as well as in adenomas and is associated with tumor size, stage and poor prognosis [17-20]. Besides its occurrence in serum, methylated HLTF has also been detected in stool samples of CRC patients $[21,22]$.

HPP1 encodes a transmembrane protein containing epidermal growth factor and follistatin domains. While reported to function as a tumor suppressor related to the STAT1 pathway earlier [23], a recently published study failed to identify tumors in HPP1 mutant mice [24]. Hypermethylation of $H P P 1$ can be detected already early in colorectal carcinogenesis [25-27]. Hyperplastic polyps and ulcerative colitis associated dysplasias as well as a several other tumor entities, including Barrett'sassociated esophageal adenocarcinoma, gastric adenocarcinoma, bladder cancer, non-small cell lung cancer and others, frequently showed HPP1 methylation [26-32].

Lactate dehydrogenase (LDH) is essential for anaerobic glycolysis and reversably converts pyruvate to lactate. Its expression has been shown to be related to the hypoxia inducible factor HIF-1 [33-36]. Activation of the HIF pathway is a common finding in cancers $[37,38]$. LDH in serum is a frequently used parameter in clinical routine and is released upon cell membrane disintegration. Thus, it is an unspecific marker for tissue damage, e.g. caused by necrosis. Elevated LDH levels can be found in numerous diseases including myocardial infarction, hemolysis and malignancies [39]. Additionally LDH has been reported to be associated with more aggressive tumors and shorter survival [40-43] in CRC. In other cancer entities like testicular cancer $[44,45]$ and aggressive non-hodgkin lymphoma [46] elevated LDH levels are used as prognostic biomarkers. Recently, LDH has been discussed as a predictive biomarker for anti-angiogenic therapies in colorectal cancer $[43,47,48]$.

Cell death, especially necrosis, is considered to be the source of circulating cell-free DNA (cfDNA) in cancer patients $[49,50]$. However, the exact mechanisms leading to the release of the tumor markers discussed here with prognostic (HLTF and HPP1) or diagnostic (NELROG1) information have not been examined so far. This study aimed at investigating a possible correlation of the presence of the methylated genes NEUROG1, HLTF and HPP1 in serum with tissue breakdown as a possible release mechanism using serum lactate dehydrogenase (LDH) as a surrogate marker. Additionally, the prognostic information given by these markers was examined.

\section{Methods}

\section{Patients and serum samples}

Pretherapeutic serum samples from 259 patients with colorectal cancer were included in the study. For these cases clinicopathologic and follow-up data as well as pretherapeutic lactate dehydrogenase values were available. Characteristics of the cohort are shown in Table 1. All measurements were performed blinded to patient data.

Table 1 Clinical features of the patient population

\begin{tabular}{llll}
\hline Clinical feature & $\begin{array}{l}\text { Number of } \\
\text { patients (\%) }\end{array}$ & $\begin{array}{l}\text { Clinical } \\
\text { feature }\end{array}$ & $\begin{array}{l}\text { Number of } \\
\text { patients (\%) }\end{array}$ \\
\hline $\begin{array}{l}\text { Total number of patients } 259 \\
\text { Age }\end{array}$ & Metastatic disease & \\
$\leq 65$ years & $129(50)$ & M0 & $170(66)$ \\
$>65$ years & $130(50)$ & M1 & $89(34)$ \\
Sex & & Tumor grade ${ }^{\text {d }}$ & \\
Male & $145(56)$ & G1 \& G2 & $132(51)$ \\
Female & $114(44)$ & G3 \& G4 & $117(45)$ \\
Tumor size ${ }^{\mathbf{b}}$ & & Localization & \\
T1 & $15(6)$ & Colon & $122(47)$ \\
T2 & $48(19)$ & Sigmoid & $47(18)$ \\
T3 & $153(59)$ & Rectum & $90(35)$ \\
T4 & $42(16)$ & UICC stage & \\
Nodal status & & I & $51(20)$ \\
N0 & $137(53)$ & ॥ & $68(26)$ \\
N1 & $66(25)$ & II & $51(20)$ \\
N2 & $50(19)$ & IV & $89(34)$ \\
\hline
\end{tabular}

${ }^{\mathrm{a}}$ Mean age: 64.8 years.

${ }^{\mathrm{b}}$ Tumor size was unknown in 1 case.

${ }^{c}$ Nodal status was unknown in 6 cases.

${ }^{\mathrm{d}}$ Tumor grade was unknown in 10 cases. 
Blood samples were obtained pretherapeutically and underwent the following standardized preanalytical procedure: All specimens were transported by a shock absorbed tube mailing system within 15 to 30 minutes after blood drawing to the central laboratory, followed by centrifugation at $2,000 \mathrm{~g}$ at $4^{\circ} \mathrm{C}$ for 10 minutes. The supernatant serum was transferred into polypropylene cryotubes and stored frozen at $-80^{\circ} \mathrm{C}$. In each case, DNA methylation and lactate dehydrogenase levels were determined in the same blood sample. The study was approved by the ethical committee of the Medical Faculty of the University of Munich.

\section{DNA isolation and bisulfite conversion}

The frozen serum samples were thawed at room temperature and homogenized by smoothly flipping the tube containing the serum. Genomic DNA from $200 \mu \mathrm{L}$ of each serum sample was isolated using the High Pure Viral Nucleic Acid Kit (Roche Applied Science, Mannheim, Germany) according to the manufacturer's instructions and eluted in $50 \mu \mathrm{l}$ of Elution Buffer. Bisulfite conversion was performed as described previously [11].

\section{Analysis of DNA methylation}

Bisulfite-treated DNA was analyzed by a fluorescencebased, real-time PCR assay, described previously as MethyLight [51]. Dispersed Alu repeats were used to control for DNA amplification and to normalize for input DNA. Primer and probe sequences are listed in Additional file 1: Table S1. PCRs were done in $20 \mu \mathrm{L}$ volumes containing $1 \mathrm{x}$ PCR buffer (Qiagen, Hilden, Germany), $4 \mathrm{mmol} / \mathrm{L} \mathrm{MgCl}$, $250 \mu \mathrm{mol} / \mathrm{L}$ deoxynucleotide triphosphate mixture, $4 \mu \mathrm{L}$ bisulfite-treated DNA, 0.05 units/ $\mu \mathrm{L}$ Taq DNA polymerase (HotStar Taq, Qiagen) along with a pair of primers and probes according to Additional file 1: Table S1. PCRs were conducted in a Mastercycler ${ }^{\circ}$ ep realplex ${ }^{4}$ (Eppendorf, Hamburg, Germany) using the following conditions: $95^{\circ} \mathrm{C}$ for $900 \mathrm{~s}$ followed by 50 cycles of $95^{\circ} \mathrm{C}$ for $30 \mathrm{~s}, 60^{\circ} \mathrm{C}$ for $120 \mathrm{~s}$, and $84^{\circ} \mathrm{C}$ for $20 \mathrm{~s}$. The specificity of all reactions for methylated DNA was confirmed by separately amplifying completely methylated and unmethylated human control DNA (Chemicon, Temecula, CA) with each set of primers and probes. The percentage of fully methylated reference (PMR) at a specific locus was calculated as described previously [51] by dividing the gene/Alu ratio of a sample by the gene/Alu ratio of fully methylated, bisulfite-treated DNA (CpGenome ${ }^{\text {тм }}$ Universal Methylated DNA, Millipore, Billerica, MA) and multiplying by 100 . A gene was considered methylated if the percentage of the fully methylated reference value was $>0$.

\section{Determination of LDH}

LDH values were determined by a UV kinetic test using the Beckman Coulter AU 2700 analyser (Beckman
Coulter GmbH, Krefeld, Germany) by the central laboratory of the university hospital of Munich. The upper limit of normal for this assay applied in everyday clinical routine is $250 \mathrm{U} / \mathrm{l}$ in our hospital. LDH levels above this value were defined as elevated in this study.

\section{Statistical analysis}

All statistical analysis was done using SAS 9.3 (SAS Institute Inc., Cary, NC). Pearson's $X^{2}$ test was used to explore associations between clinicopathologic features and categorized variables. Associations between categorized and continuous variables were tested by means of the Wilcoxon-Mann-Whitney test and correlations between continuous variables were examined using Spearman Correlation Coefficients. For evaluation of simultaneous influence of clinicopathologic features and methylation markers on $\mathrm{LDH}$ values a multivariate logistic regression model was developed. Overall survival was calculated from the date of diagnosis of the primary tumor to the date of death or end of follow-up. Univariate analysis of overall survival according to gene methylation status and LDH values was performed using the Kaplan-Meier method and log-rank tests.

\section{Results}

Clinicopathologic features and DNA methylation in serum A total number of 259 serum samples were analyzed. An overview of the clinocopathologic characteristics is shown in Table 1. Methylation of HLTF was detected in 41 cases (16\%), methylation of HPP1 in 57 cases (22\%) and methylation of NEUROG1 in 66 cases (25\%). The distribution of PMR values is demonstrated in Additional file 2: Table S2. HLTF methylation in the serum was significantly correlated with metastatic diseases $(p=0.013)$ and advanced tumor stages $(\mathrm{p}=0.0489)$ as well as T4 tumors (T1-3 vs. $\mathrm{T} 4, \mathrm{p}=0.046)$. A non-significant trend towards spread to lymph nodes was observed (N0 vs. N1-2, p = 0.050). HPP1 methylation in serum was significantly correlated with larger tumor size $(\mathrm{p}<0.001)$, positive nodal status $(\mathrm{p}<0.0001)$, metastatic disease $(\mathrm{p}<0.0001)$, tumor stage $(\mathrm{p}<.0001)$ as well as higher tumor grades $(\mathrm{p}=0.0002)$. No significant correlation between NEUROG1 methylation and clinicopathologic features existed. The complete distribution of the markers among the clinicopathologic features is presented in Table 2.

$\mathrm{LDH}$ values ranged from 100 to $1730 \mathrm{U} / \mathrm{l}$ with a mean value of $238 \mathrm{U} / \mathrm{l}$ (standard deviation $202 \mathrm{U} / \mathrm{l}$ ) and a median value of $185 \mathrm{U} / \mathrm{l}$. A cutoff of $250 \mathrm{U} / \mathrm{l}$, representing the upper limit of normal of the assay used, was chosen, resulting in 50 patients (19\%) with elevated LDH levels. These patients suffered more frequently from $\mathrm{T} 4 \mathrm{tu}-$ mors (T1-3 vs. T4, $\mathrm{p}=0.038$ ), nodal and distant metastases $(\mathrm{p}=0.0006$ and $\mathrm{p}<0.0001$, respectively) as well as higher tumor stages $(\mathrm{p}<0.0001)$. Additionally, a non- 
Table 2 Distribution of LDH and methylation of HLTF, HPP1 and NEUROG1 among clinicopathologic features

\begin{tabular}{|c|c|c|c|c|c|c|c|c|}
\hline \multirow[t]{2}{*}{ Clinical feature } & \multicolumn{2}{|c|}{$\mathrm{LDH} \geq 250 \mathrm{U} / \mathrm{I}$} & \multicolumn{2}{|c|}{ HLTF methylation } & \multicolumn{2}{|c|}{ HPP1 methylation } & \multicolumn{2}{|c|}{ NEUROG1 methylation } \\
\hline & n (\%) & $\mathbf{P}$ & n (\%) & $\mathbf{P}$ & n (\%) & $\mathbf{P}$ & n (\%) & $p$ \\
\hline Total positive & $50(19)$ & & $41(16)$ & & $57(22)$ & & $66(25)$ & \\
\hline \multicolumn{9}{|l|}{$\mathrm{Age}^{\mathrm{a}}$} \\
\hline$\leq 65$ years & $31(24)$ & & $18(14)$ & & $31(24)$ & & $36(28)$ & \\
\hline$>65$ years & $19(15)$ & 0.055 & $23(18)$ & 0.410 & $26(20)$ & 0.434 & $30(23)$ & 0.372 \\
\hline \multicolumn{9}{|l|}{ Sex } \\
\hline Male & $26(18)$ & & $22(15)$ & & $34(23)$ & & $34(23)$ & \\
\hline Female & $24(21)$ & 0.528 & $19(17)$ & 0.744 & $23(20)$ & 0.528 & $32(28)$ & 0.397 \\
\hline \multicolumn{9}{|l|}{ Tumor size $^{a}$} \\
\hline T1 & $0(0)$ & & $2(13)$ & & $1(7)$ & & $4(27)$ & \\
\hline T2 & $9(19)$ & & $3(6)$ & & $3(6)$ & & $12(25)$ & \\
\hline T3 & $28(18)$ & & $25(16)$ & & $32(21)$ & & $39(25)$ & \\
\hline T4 & $13(31)$ & 0.062 & $11(27)$ & 0.080 & $20(48)$ & $<.0001$ & $11(26)$ & 0.999 \\
\hline \multicolumn{9}{|l|}{ Nodal status $^{b}$} \\
\hline No & $14(10)$ & & $16(12)$ & & $13(9)$ & & $37(27)$ & \\
\hline N1 & $19(29)$ & & $13(20)$ & & $23(35)$ & & $13(20)$ & \\
\hline N2 & $15(30)$ & 0.0006 & $11(22)$ & 0.139 & $18(36)$ & $<.0001$ & $16(32)$ & 0.307 \\
\hline \multicolumn{9}{|c|}{ Metastatic disease } \\
\hline MO & $13(8)$ & & $20(12)$ & & $10(6)$ & & $48(28)$ & \\
\hline M1 & $37(42)$ & $<.0001$ & $21(24)$ & 0.013 & $47(53)$ & $<.0001$ & $18(20)$ & 0.160 \\
\hline \multicolumn{9}{|l|}{ Localization } \\
\hline Colon & $25(20)$ & & $22(18)$ & & $33(27)$ & & $38(31)$ & \\
\hline Sigmoid & $9(19)$ & & $10(21)$ & & $8(17)$ & & $8(17)$ & \\
\hline Rectum & $9(19)$ & 0.884 & $9(10)$ & 0.151 & $16(18)$ & 0.180 & $20(22)$ & 0.114 \\
\hline \multicolumn{9}{|l|}{ Tumor grade $^{c}$} \\
\hline $\mathrm{G} 1 \& \mathrm{G} 2$ & $22(17)$ & & $16(12)$ & & $16(12)$ & & $37(28)$ & \\
\hline G3 \& G4 & $25(21)$ & 0.344 & $23(20)$ & 0.102 & $37(32)$ & 0.0002 & $27(23)$ & 0.372 \\
\hline \multicolumn{9}{|l|}{ UICC stage } \\
\hline 1 & $6(12)$ & & $4(8)$ & & $2(4)$ & & $16(31)$ & \\
\hline$\|$ & $4(6)$ & & $11(16)$ & & $4(6)$ & & $19(28)$ & \\
\hline III & $3(6)$ & & $5(10)$ & & $4(8)$ & & $13(25)$ & \\
\hline IV & $37(42)$ & $<.0001$ & $21(24)$ & 0.049 & $47(53)$ & $<.0001$ & $18(20)$ & 0.486 \\
\hline
\end{tabular}

a Tumor size was unknown in 1 case.

${ }^{\mathrm{b}}$ Nodal status was unknown in 6 cases.

'Tumor grade was unknown in 10 cases.

significant trend towards higher LDH levels in younger patients was found $(\mathrm{p}=0.055)$.

Correlation between LDH and DNA methylation in serum First we analyzed the correlation of methylation of HLTF, HPP1 and NEUROG1 with LDH in a binary way. For this purpose we used a cutoff of LDH at $250 \mathrm{U} / \mathrm{l}$ as mentioned above. For the methylation markers we considered a PMR $>0$ as methylation positive which has been shown previously to be reasonable for serum methylation analysis by our and other groups [10,52,53]. In the 50 samples with elevated LDH levels, methylation of HLTF, HPP1, or NEUROG1 was detected in 16 (32\%), 34 (68\%), or 12 cases $(24 \%)$, respectively, compared to 25 (12\%), 23 $(11 \%)$, or $54(26 \%)$ in those 209 samples with normal LDH levels. Patients with elevated LDH levels revealed significantly more often methylation of HLTF or HPP1 ( $\mathrm{p}=0.0005$ or $\mathrm{p}<0.0001$, respectively), whereas no correlation between NEUROG1 methylation and elevated $\mathrm{LDH}$ was found.

We also examined the relation of the methylation markers between each other. Methylation of HLTF was 
found significantly more often in HPP1 positive samples ( $51 \%$ vs. $17 \%, \mathrm{p}<0.0001$ ). No significant difference in the frequency of either HLTF or HPP1 methylation was observed between NEUROG1 positive and NEUROG1 negative cases ( $32 \%$ vs. $24 \%$ and $26 \%$ vs. $25 \%$, respectively).

In a second step, correlations were analyzed using LDH as a continous variable without cutoff. In HPP1 positive samples significantly higher LDH levels were measured (median $298 \mathrm{U} / \mathrm{l}$ vs. $173 \mathrm{U} / \mathrm{l}, \mathrm{p}<0.0001$ ). Patients with methylation of HLTF had slightly, but still significantly higher LDH levels (median $208 \mathrm{U} / \mathrm{l}$ vs. $180 \mathrm{U} / \mathrm{l}, \mathrm{p}=0.0050$ ), while no difference was found in LDH levels between NEUROG1 positive and negative samples (median $187 \mathrm{U} / \mathrm{L}$ vs. $184 \mathrm{U} / \mathrm{l}, \mathrm{p}=0.95)$. Figure 1 provides a more detailed view on the distribution of LDH levels among the three methylation markers.

Additionally, we tested HLTF, HPP1 and NEUROG1 as continuous variables without cutoff using the PMR values and calculated univariate Spearman correlation coefficients. As in the analyses before, HLTF and HPP1 showed significant correlation with LDH, while NEUROG1 did not. All linear correlation coefficients and p-values are presented in Table 3.

\section{Multivariate model}

Next, a multivariate model was developed using logistic regression analysis with $\mathrm{LDH}$ values higher than $250 \mathrm{U} / \mathrm{l}$ as target variable. HPP1 and HLTF methylation as binary parameters, i.e. with a PMR $>0$, as well as clinicopathological features were entered as independent variables. Only presence of distant metastases and HPP1 correlated significantly and independently with elevated LDH levels higher than $250 \mathrm{U} / \mathrm{l}$. The odds ratios were $3.1 \mathrm{for}$ metastatic disease (95\% CI 1.3-7.2, $\mathrm{p}=0.009)$ and 9.5 for HPP1 methylation (95\% CI 4.2-21.9, $\mathrm{p}<0.0001)$.

\section{Survival analysis}

We earlier reported methylation of HLTF and HPP1 to be independent prognostic markers in metastastatic colorectal cancer [11]. On the other hand, elevated LDH levels have been described to be linked to shorter survival [54]. Thus we compared methylation of HLTF and HPP1 with LDH as prognostic factors in our patient population.

As reported earlier [11] methylation of HLTF and HPP1 was associated with a higher mortality. In the current study, the median survival was 6.4 years (95\% CI 4.9-9.0) and 8.0 years (95\% CI 6.1-11.2) for HLTF- and HPP1negative cases compared to 3.7 years (95\% CI 1.1-5.2) and 1.2 years (95\% CI 0.9-1.9) in case of positivity for HLTF or HPP1 methylation $(\mathrm{p}=0.0008$ and $\mathrm{p}<0.0001)$, respectively (Figure 2A, 2B). LDH levels above a cutoff of $250 \mathrm{U} / \mathrm{l}$ were associated with shorter overall survival (median survival 1.1 years, 95\% CI 0.9-2.0) compared to low LDH levels (median survival 7.2 years, 95\% CI 5.6-9.6) $(\mathrm{p}<0.0001)$ (Figure 2C).

Next, we evaluated the prognostic significance stratified by tumor stage. For patients with UICC stage I-III no significant difference in overall survival, neither for LDH ( $\mathrm{p}=0.41)$ nor for HLTF and HPP1 ( $\mathrm{p}=0.41$ and $\mathrm{p}=0.08$, respectively), was found. However, in stage IV HLTF methylation positive patients showed a median survival of 0.86 years $(95 \%$ CI $0.5-1.2)$ versus 1.6 years (95\% CI 1.2-2.3) for HLTF negative cases ( $\mathrm{p}=0.0081$; Figure 2D). For $H P P 1$ positive and negative cases the median survival was 1.0 years (95\% CI $0.6-1.4)$ and

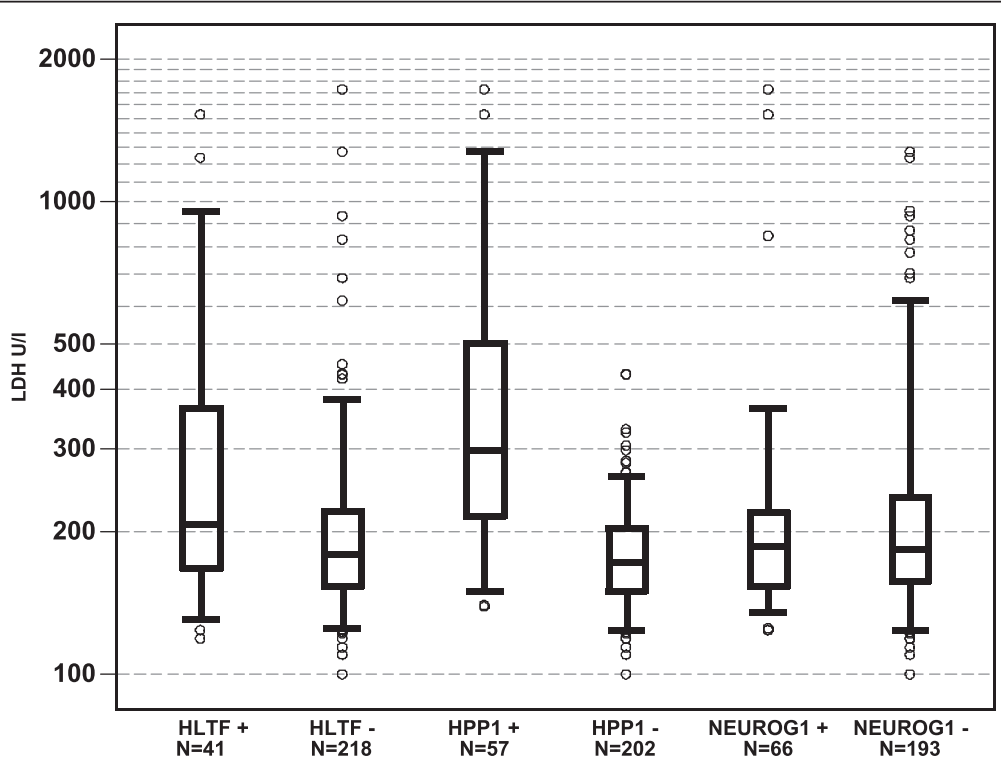

Figure $1 \mathrm{LDH}$ values and methylation status of HLTF, HPP1 and NEUROG1 (as binary variables, cutoff PMR $>0$ ). 
Table 3 Linear Spearman correlation coefficients for the percentage of fully methylated reference (PMR) of HLTF, HPP1 and NEUROG1, and LDH levels among each other

\begin{tabular}{lllll}
\hline & PMR HLTF & PMR HPP1 & PMR NEUROG1 & LDH \\
\hline PMR HLTF & 1.0 & - & - & - \\
PMR HPP1 & $0.32(p<.0001)$ & 1.0 & - & - \\
PMR & $0.05(p=0.41)$ & $-0.00(p=0.97)$ & 1.0 & - \\
NEUROG1 & & & & \\
LDH & $0.18(p=0.004)$ & $0.49(p<.0001)$ & $0.01(p=0.85)$ & 1.0 \\
\hline
\end{tabular}

1.8 years (95\% CI $1.2-3.3)$, respectively $(\mathrm{p}=0.0005$; Figure 2E). For LDH, elevated levels $>250 \mathrm{U} / \mathrm{l}$ were associated with shorter median survival (1.0 years, 95\% CI 0.6-1.2, vs. 1.8 years, 95\% CI 1.3-2.5; $\mathrm{p}=0.0002$; Figure 2F).

\section{Discussion}

In this study we examined the correlation between cell damage using LDH as a surrogate marker and the methylation status of three genes which have previously been proposed as prognostic (HLTF, HPP1) $[10,11]$ or diagnostic (NEUROG1) [8] biomarkers for patients with CRC.

Our data confirm our previous findings that methylation of HLTF or HPP1 in serum is found more often in
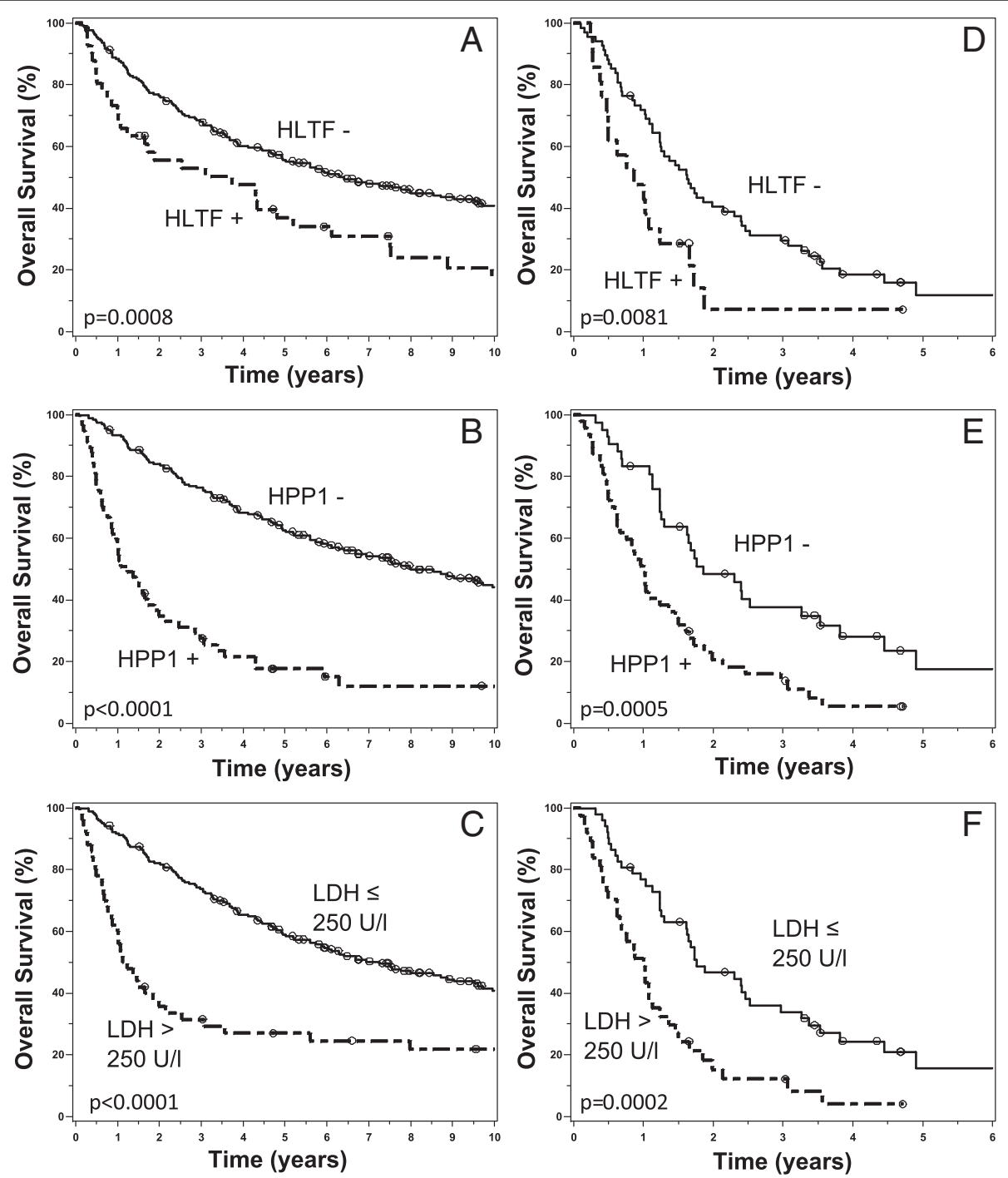

Figure 2 Kaplan-Meier plots of overall survival. A-C: Overall survival for all patients according to methylation status of HLTF (A), HPP1 (B) and high $\mathrm{LDH}$ levels > $250 \mathrm{U/I}$ (C), respectively. D-F: Overall survival for stage IV patients patients according to methylation status of HLTF (D), HPP1 (E) and high LDH levels $>250 \mathrm{U} / \mathrm{I}(\mathbf{F})$, respectively. 
patients with advanced stages of colorectal cancer, especially in those with distant metastases, whereas no correlation between methylation of NEUROG1 and any clinicopathologic data was found. While methylation of HLTF was only correlated with metastastatic disease, methylation of HPP1 was also associated with local tumor extent and nodal status as well as tumor grade with high statistic significance.

It is well known that patients with elevated serum levels of LDH tend to have more aggressive tumors and a shorter survival time [40-43]. Consistent with the literature high LDH levels in our data were significantly correlated with advanced tumor stages as well as nodal and distant metastases. Trends towards larger tumor size and younger age were observed but did not reach statistical significance.

Cell death associated mechanisms like apoptosis or, especially in cancer, necrosis have been suggested as main sources for cell-free DNA (cfDNA) in the blood, but other mechanisms like physiological active release have been described as well (for reviews see refs. [49,50]). In this study we found methylation of HLTF and, even to a higher degree, HPP1 to be correlated with elevated LDH levels. This finding was robust, as it was confirmed by different statistical methods. Given that elevated LDH indicates cell membrane damage, this observation might be a hint that methylated HLTF and HPP1 DNA is released by tumor cells undergoing cell death. The fact that necrosis tends to be found more often in larger, more aggressive tumours and advanced cancer stages $[55,56]$, which was likewise the case for $\mathrm{LDH}$ as well as methylated HLTF and HPP1 in our data, also suggests an interrelation.

For NEUROG1, on the other hand, hypermethylation in serum was detectable independently of LDH levels and tumor stage. This is consistent with earlier analyses revealing methylation of NEUROG1 in primary tissue not to be associated with tumor stage (A.P. and F.K., data not published). Hence the observed correlation between DNA methylation in serum and LDH seems not to be linked to global methylation levels and cell death alone. Besides the methylation status of distinct genes, other parameters influencing this observation might include DNA integrity and stability of the respective segments as well as still unknown factors. Therefore it seems likely that tumor cell death might not be the only mechanism by which methylated tumor DNA is released to the blood.

In addition to the correlation analysis we examined the prognostic significance of the methylation markers HPP1 and HLTF as well as of LDH. All three markers were significantly associated with worse overall survival. This could be attributed to the fact that all three markers are found more frequently in advanced cancer stages. However, earlier analyses [11] as well as the survival data presented here furthermore divide patients with already metastasized disease into two subgroups with better or worse prognosis, respectively.

\section{Conclusion}

In conclusion we were able to provide evidence that methylation of HLTF and especially HPP1 detected in serum is strongly correlated with cell death in colorectal cancer using LDH as surrogate marker. However, this finding was specific for those two genes and did not occur for NEUROG1, suggesting that mechanisms other than release by membrane disintegration could be responsible for the occurrence of cell-free DNA in blood of CRC patients. Additionally, we found that prognostic information is given by both HLTF and HPP1 as well as LDH. In sum, determining the methylation of HLTF and HPP1 in serum might be useful in order to identify patients with more aggressive tumors. Future research needs to further clarify the underlying biological mechanisms and to validate methylated cell-free circulating DNA as a biomarker for colorectal cancer.

\section{Additional files}

Additional file 1: MethyLight Reaction Details.

Additional file 2: Distribution of the percentage of fully methylated reference (PMR) of HLTF, HPP1 and NEUROG1.

\section{Abbreviations}

cfDNA: Cell-free deoxyribonucleic acid; Cl: Confidence interval; CIMP: CpG island methylator phenotype; CRC: Colorectal cancer; HIF: Hypoxia inducible factor; HLTF: Helicase-like transcription factor; HPP1: Hyperplastic polyposis; LDH: Lactate dehydrogenase; NEUROG1: Neurogenin 1; PCR: Polymerase chain reaction; PMR: Percentage of fully methylated reference; UICC: Union for international cancer control; UV: Ultraviolet.

\section{Competing interests}

The authors declare that they have no competing interest.

\section{Authors' contributions}

Sample collection and experiments: AP, IT, PS, and RL; data analysis and interpretation: AP, DN, PS, and FK; study design and preparation of the manuscript: AP, AH, and FK. All authors read and approved the final manuscript.

\section{Financial support}

Medical Faculty of the University of Munich.

\section{Author details}

'Department of Medicine II, Ludwig-Maximilians-Universität München, Marchioninistr. 15, 81377 Munich, Germany. ${ }^{2}$ Institute of Laboratory Medicine, Ludwig-Maximilians-Universität München, Munich, Germany.

Received: 30 September 2013 Accepted: 3 April 2014 Published: 8 April 2014

\section{References}

1. Ferlay J, Shin HR, Bray F, Forman D, Mathers C, Parkin DM: Estimates of worldwide burden of cancer in 2008: GLOBOCAN 2008. Int J Cancer 2010, 127:2893-2917. 
2. O'Connell JB, Maggard MA, Ko CY: Colon cancer survival rates with the new American Joint Committee on Cancer sixth edition staging. J Natl Cancer Inst 2004, 96:1420-1425

3. Jones PA, Baylin SB: The epigenomics of cancer. Cell 2007, 128:683-692

4. Baylin SB, Ohm JE: Epigenetic gene silencing in cancer - a mechanism for early oncogenic pathway addiction? Nat Rev Cancer 2006, 6:107-116.

5. Duffy MJ, Napieralski R, Martens JWM, Span PN, Spyratos F, Sweep FCGJ, Brunner N, Foekens JA, Schmitt M: Methylated genes as new cancer biomarkers. Eur J Cancer 2009, 45:335-346.

6. Kim MS, Lee J, Sidransky D: DNA methylation markers in colorectal cancer. Cancer Metastasis Rev 2010, 29:181-206.

7. Herbst A, Kolligs FT: Detection of DNA hypermethylation in remote media of patients with colorectal cancer: new biomarkers for colorectal carcinoma. Tumour Biol 2012, 33:297-305.

8. Herbst A, Rahmig K, Stieber P, Philipp A, Jung A, Ofner A, Crispin A, Neumann J, Lamerz R, Kolligs FT: Methylation of NEUROG1 in Serum Is a Sensitive Marker for the Detection of Early Colorectal Cancer. Am J Gastroenterol 2011, 106:1110-1118.

9. Lenhard K, Bommer GT, Asutay S, Schauer R, Brabletz T, Göke B, Lamerz R, Kolligs FT: Analysis of promoter methylation in stool: a novel method for the detection of colorectal cancer. Clin Gastroenterol Hepatol 2005, 3:142-149.

10. Wallner M, Herbst A, Behrens A, Crispin A, Stieber P, Göke B, Lamerz R, Kolligs FT: Methylation of serum DNA is an independent prognostic marker in colorectal cancer. Clin Cancer Res 2006, 12:7347-7352.

11. Philipp AB, Stieber P, Nagel D, Neumann J, Spelsberg F, Jung A, Lamerz R, Herbst A, Kolligs FT: Prognostic role of methylated free circulating DNA in colorectal cancer. Int J Cancer 2012, 131:2308-2319.

12. Pan N, Kopecky B, Jahan I, Fritzsch B: Understanding the evolution and development of neurosensory transcription factors of the ear to enhance therapeutic translation. Cell Tissue Res 2012, 349:415-432.

13. Weisenberger DJ, Siegmund KD, Campan M, Young J, Long TI, Faasse MA, Kang $\mathrm{GH}$, Widschwendter M, Weener D, Buchanan D, Koh H, Simms L, Barker M, Leggett B, Levine J, Kim M, French AJ, Thibodeau SN, Jass J, Haile $R$, Laird PW: CpG island methylator phenotype underlies sporadic microsatellite instability and is tightly associated with BRAF mutation in colorectal cancer. Nat Genet 2006, 38:787-793.

14. Ogino S, Cantor M, Kawasaki T, Brahmandam M, Kirkner GJ, Weisenberger DJ, Campan M, Laird PW, Loda M, Fuchs CS: CpG island methylator phenotype (CIMP) of colorectal cancer is best characterised by quantitative DNA methylation analysis and prospective cohort studies. Gut 2006, 55:1000-1006.

15. Sandhu S, Wu X, Nabi Z, Rastegar M, Kung S, Mai S, Ding H: Loss of HLTF function promotes intestinal carcinogenesis. Mol Cancer 2012, 11:18.

16. Debauve G, Capouillez A, Belayew A, Saussez S: The helicase-like transcription factor and its implication in cancer progression. Cell Mol Life Sci 2008 65:591-604

17. Moinova HR, Chen W-D, Shen L, Smiraglia D, Olechnowicz J, Ravi L, Kasturi L, Myeroff L, Plass C, Parsons R, Minna J, Willson JKV, Green SB, Issa J-P, Markowitz SD: HLTF gene silencing in human colon cancer. Proc Natl Acad Sci U S A 2002, 99:4562-4567.

18. Bai AHC, Tong JHM, To K-F, Chan MWY, Man EPS, Lo K-W, Lee JFY, Sung JJY, Leung WK: Promoter hypermethylation of tumor-related genes in the progression of colorectal neoplasia. Int J Cancer 2004, 112:846-853.

19. Hibi K, Nakao A: Highly-methylated colorectal cancers show poorlydifferentiated phenotype. Anticancer Res 2006, 26:4263-4266.

20. Kim Y, Petko Z, Dzieciatkowski S, Lin L, Ghiassi M, Stain S, Chapman WC, Washington MK, Willis J, Markowitz SD, Grady WM: CpG island methylation of genes accumulates during the adenoma progression step of the multistep pathogenesis of colorectal cancer. Genes Chromosomes Cancer 2006, 45:781-789.

21. Leung WK, To K-F, Man EPS, Chan MWY, Bai AHC, Hui AJ, Chan FKL, Lee JFY, Sung JJY: Detection of epigenetic changes in fecal DNA as a molecular screening test for colorectal cancer: a feasibility study. Clin Chem 2004, 50:2179-2182.

22. Leung WK, To K-F, Man EPS, Chan MWY, Hui AJ, Ng SSM, Lau JYW, Sung JJY: Detection of hypermethylated DNA or cyclooxygenase-2 messenger RNA in fecal samples of patients with colorectal cancer or polyps. Am J Gastroenterol 2007, 102:1070-1076.

23. Elahi A, Zhang L, Yeatman TJ, Gery S, Sebti S, Shibata D: HPP1-mediated tumor suppression requires activation of STAT1 pathways. Int J Cancer 2008, 122:1567-1572.
24. Chen TR, Wang P, Carroll LK, Zhang Y, Han B-X, Wang F: Generation and characterization of Tmeff2 mutant mice. Biochem Biophys Res Commun 2012, 425:189-194.

25. Ebert MP, Mooney SH, Tonnes-Priddy L, Lograsso J, Hoffmann J, Chen J, Röcken C, Schulz H-U, Malfertheiner P, Lofton-Day C: Hypermethylation of the TPEF/HPP1 Gene in Primary and Metastatic Colorectal Cancers. Neoplasia 2005, 7:771-778.

26. Young J, Biden KG, Simms LA, Huggard P, Karamatic R, Eyre HJ, Sutherland GR, Herath N, Barker M, Anderson GJ, Fitzpatrick DR, Ramm GA, Jass JR Leggett BA: HPP1: a transmembrane protein-encoding gene commonly methylated in colorectal polyps and cancers. Proc Natl Acad Sci U S A 2001, 98:265-270.

27. Sato F, Shibata D, Harpaz N, Xu Y, Yin J, Mori Y, Wang S, Olaru A, Deacu E, Selaru FM, Kimos MC, Hytiroglou P, Young J, Leggett B, Gazdar AF, Toyooka S, Abraham JM, Meltzer SJ: Aberrant methylation of the HPP1 gene in ulcerative colitis-associated colorectal carcinoma. Cancer Res 2002, 62:6820-6822.

28. Saito S, Kato J, Hiraoka S, Horii J, Suzuki H, Higashi R, Kaji E, Kondo Y, Yamamoto K: DNA methylation of colon mucosa in ulcerative colitis patients: Correlation with inflammatory status. Inflamm Bowel Dis 2011 17:1955-1965.

29. Eads CA, Lord RV, Kurumboor SK, Wickramasinghe K, Skinner ML, Long TI, Peters JH, DeMeester TR, Danenberg KD, Danenberg PV, Laird PW, Skinner KA: Fields of aberrant CpG island hypermethylation in Barrett's esophagus and associated adenocarcinoma. Cancer Res 2000, 60:5021-5026.

30. Ivanauskas A, Hoffmann J, Jonaitis LV, Markelis R, Juozaityte E, Kupcinskas L, Lofton-Day C, Röcken C, Malfertheiner P: Distinct TPEF/HPP1 gene methylation patterns in gastric cancer indicate a field effect in gastric carcinogenesis. Dig Liver Dis 2008, 40:920-926.

31. Hellwinkel OJC, Kedia M, Isbarn H, Budäus L, Friedrich MG: Methylation of the TPEF- and PAX6-promoters is increased in early bladder cancer and in normal mucosa adjacent to pTa tumours. BJU Int 2008, 101:753-757.

32. Lee SM, Park JY, Kim DS: Methylation of TMEFF2 gene in tissue and serum DNA from patients with non-small cell lung cancer. Mol Cells 2012, 34:171-176

33. Semenza GL, Roth PH, Fang HM, Wang GL: Transcriptional regulation of genes encoding glycolytic enzymes by hypoxia-inducible factor 1. J Biol Chem 1994, 269:23757-23763

34. Firth JD, Ebert BL, Pugh CW, Ratcliffe PJ: Oxygen-regulated control elements in the phosphoglycerate kinase 1 and lactate dehydrogenase A genes: similarities with the erythropoietin 3' enhancer. Proc Natl Acad Sci U S A 1994, 91:6496-6500.

35. Firth JD, Ebert BL, Ratcliffe PJ: Hypoxic regulation of lactate dehydrogenase A. Interaction between hypoxia-inducible factor 1 and cAMP response elements. J Biol Chem 1995, 270:21021-21027.

36. Weidemann A, Johnson RS: Biology of HIF-1alpha. Cell Death Differ 2008, 15:621-627

37. Maxwell PH, Pugh CW, Ratcliffe PJ: Activation of the HIF pathway in cancer. Curr Opin Genet Dev 2001, 11:293-299.

38. Keith B, Johnson RS, Simon MC: HIF1a and HIF2a: sibling rivalry in hypoxic tumour growth and progression. Nat Rev Cancer 2012, 12:9-22.

39. Huijgen HJ, Sanders GT, Koster RW, Vreeken J, Bossuyt PM: The clinical value of lactate dehydrogenase in serum: a quantitative review. Eur J Clin Chem Clin Biochem 1997, 35:569-579.

40. Mekenkamp LJM, Koopman M, Teerenstra S, van Krieken JHJM, Mol L, Nagtegaal ID, Punt CJA: Clinicopathological features and outcome in advanced colorectal cancer patients with synchronous vs metachronous metastases. Br J Cancer 2010, 103:159-164.

41. De Gramont A, Figer A, Seymour M, Homerin M, Hmissi A, Cassidy J, Boni C, Cortes-Funes H, Cervantes A, Freyer G, Papamichael D, Le Bail N, Louvet C, Hendler D, de Braud F, Wilson C, Morvan F, Bonetti A: Leucovorin and fluorouracil with or without oxaliplatin as first-line treatment in advanced colorectal cancer. J Clin Oncol 2000, 18:2938-2947.

42. Wu X, Ma F, Wang X-L: Serological diagnostic factors for liver metastasis in patients with colorectal cancer. World J Gastroenterol 2010, 16:4084-4088

43. Scartozzi M, Giampieri R, Maccaroni E, Del Prete M, Faloppi L, Bianconi M, Galizia E, Loretelli C, Belvederesi L, Bittoni A, Cascinu S: Pre-treatment lactate dehydrogenase levels as predictor of efficacy of first-line bevacizumab-based therapy in metastatic colorectal cancer patients. $\mathrm{Br} \mathrm{J}$ Cancer 2012, 106:799-804. 
44. International Germ Cell Cancer Collaborative Group: Germ Cell Consensus Classification: a prognostic factor-based staging system for metastatic germ cell cancers. International Germ Cell Cancer Collaborative Group. J Clin Oncol 1997, 15:594-603.

45. Krege S, Beyer J, Souchon R, Albers P, Albrecht W, Algaba F, Bamberg M, Bodrogi I, Bokemeyer C, Cavallin-Ståhl E, Classen J, Clemm C, CohnCedermark G, Culine S, Daugaard G, De Mulder PHM, De Santis M, de Wit M, de Wit R, Derigs HG, Dieckmann K, Dieing A, Droz J, Fenner M, Fizazi K, Flechon A, Fosså SD, del Muro XG, Gauler T, Geczi L, et al: European consensus conference on diagnosis and treatment of germ cell cancer: a report of the second meeting of the European Germ Cell Cancer Consensus group (EGCCCG): part I. Eur Urol 2008, 53:478-496.

46. A predictive model for aggressive non-Hodgkin's lymphoma. The International Non-Hodgkin's Lymphoma Prognostic Factors Project. N Engl J Med 1993, 329:987-994.

47. Hecht JR, Trarbach T, Hainsworth JD, Major P, Jäger E, Wolff RA, LloydSalvant K, Bodoky G, Pendergrass K, Berg W, Chen B-L, Jalava T, Meinhardt G, Laurent D, Lebwohl D, Kerr D: Randomized, placebo-controlled, phase III study of first-line oxaliplatin-based chemotherapy plus PTK787/ZK 222584, an oral vascular endothelial growth factor receptor inhibitor, in patients with metastatic colorectal adenocarcinoma. J Clin Oncol 2011, 29:1997-2003.

48. Van Cutsem E, Bajetta E, Valle J, Köhne C-H, Randolph Hecht J, Moore M, Germond C, Berg W, Chen B-L, Jalava T, Lebwohl D, Meinhardt G, Laurent D, Lin E: Randomized, placebo-controlled, phase III study of oxaliplatin, fluorouracil, and leucovorin with or without PTK787/ZK 222584 in patients with previously treated metastatic colorectal adenocarcinoma. J Clin Oncol 2011, 29:2004-2010.

49. Jung K, Fleischhacker M, Rabien A: Cell-free DNA in the blood as a solid tumor biomarker-a critical appraisal of the literature. Clin Chim Acta 2010, 411:1611-1624.

50. Schwarzenbach H, Hoon DSB, Pantel K: Cell-free nucleic acids as biomarkers in cancer patients. Nat Rev Cancer 2011, 11:426-437.

51. Eads CA, Danenberg KD, Kawakami K, Saltz LB, Blake C, Shibata D, Danenberg PV, Laird PW: MethyLight: a high-throughput assay to measure DNA methylation. Nucleic Acids Res 2000, 28:E32.

52. Müller HM, Widschwendter A, Fiegl H, Ivarsson L, Goebel G, Perkmann E, Marth C, Widschwendter M: DNA methylation in serum of breast cancer patients: an independent prognostic marker. Cancer Res 2003, 63:7641-7645

53. Ebert MP, Model F, Mooney S, Hale K, Lograsso J, Tonnes-Priddy L, Hoffmann J, Csepregi A, Röcken C, Molnar B, Schulz H-U, Malfertheiner P, Lofton-Day C: Aristaless-like homeobox-4 gene methylation is a potential marker for colorectal adenocarcinomas. Gastroenterology 2006 131:1418-1430.

54. Tas F, Aykan F, Alici S, Kaytan E, Aydiner A, Topuz E: Prognostic factors in pancreatic carcinoma: serum LDH levels predict survival in metastatic disease. Am J Clin Oncol 2001, 24:547-550.

55. Pollheimer MJ, Kornprat P, Lindtner RA, Harbaum L, Schlemmer A, Rehak P, Langner $C$ : Tumor necrosis is a new promising prognostic factor in colorectal cancer. Hum Pathol 2010, 41:1749-1757.

56. Richards CH, Roxburgh CSD, Anderson JH, McKee RF, Foulis AK, Horgan PG, McMillan DC: Prognostic value of tumour necrosis and host inflammatory responses in colorectal cancer. Br J Surg 2012, 99:287-294.

\section{Submit your next manuscript to BioMed Central and take full advantage of:}

- Convenient online submission

- Thorough peer review

- No space constraints or color figure charges

- Immediate publication on acceptance

- Inclusion in PubMed, CAS, Scopus and Google Scholar

- Research which is freely available for redistribution 